\title{
AND MANAGEMENT
}

Citation: Kuşat, N., 2020. Yeni Dünya Düzeninde Ekonomik Egemenlik - Ulus Devlet Çelişkisi,

International Review of Economics and Management, 8(2), 221-240. Doi: http://dx.doi.org/10.18825/iremjournal.706965

\section{YENI DÜNYA DÜZENINDE EKONOMIK EGEMENLIK - ULUS DEVLET ÇELIŞKISi}

\author{
Nurdan KUŞAT* \\ Başvuru Tarihi: 20 / 03 / 2020 - Kabul Tarihi: 17 / 12 / 2020
}

\section{Özet}

Yeni ekonomik düzenin en önemli yapı taşı olan 'Küreselleşme', ekonomik, sosyal, siyasal, kültürel vb. pek çok alanda etkili olmaktadır. Küreselleşmenin yapılandırdığı bu yeni düzenin en önemli sonucu ise tüm ulus devletlerin diğer ulus devletler ve uluslararası kurum ve kuruluşlarla uzun vadeli ilişkiler içerisine girmelerini tetiklemesidir. Fakat bu süreç birçok ulusal yapı, kurum ve kavramın değişip evrilmesine ve her şeyden öte 'ulus devlet' olgusunun da aşınmasına zemin hazırlamaktadır. Bu çalışmanın amacı, geleneksel ulus devlet anlayışının en önemli yapı taşlarından olan ekonomik egemenlik olgusunun, küreselleşme süreci sonrasında yaşadığı değişim ve dönüşümü incelemektedir.

Anahtar Kelimeler: Küreselleşme, Ulus Devlet, Uluslararası Kuruluşlar, Ekonomik Egemenlik, Ulus Üstü Devlet.

Jel Kodları: F52, F68

\footnotetext{
* Doç. Dr., Isparta Uygulamalı Bilimler Üniversitesi, Isparta Meslek Yüksekokulu, Dış Ticaret Bölümü, nurdankusat@isparta.edu.tr, 


\title{
ECONOMIC HEGEMONY - NATION STATE PARADOX WITHIN THE PROCESS OF NEW WORLD ORDER
}

\begin{abstract}
'Globalization', which is the most important building block of the new economic order, is effective in many areas such as economic, social, political, cultural, etc. The most significant outcome of this new order, which has been created and shaped by globalization is that it triggers all nation states to enter into long-term relations with other nation states and international institutions and organizations. However, this process paves the way for many national structures, institutions and concepts to change and evolve and moreover erode the 'nation state' phenomenon. The purpose of this study is to examine the change and transformation of the phenomenon of economic hegemony, which is one of the most important building blocks of traditional nation state understanding, after the globalization process.
\end{abstract}

Keywords: Globalization, Nation State, International Organizations, Economic Hegemony, Supranational State.

Jel Classification: F52, F68

\section{GİRIS}

20. yy'ın son çeyreğine damgasını vuran küreselleşme olgusu, bilişim teknolojilerindeki hızlı gelişmelerin önderliğinde ve uluslararası sermaye hareketlerinin ivmelemeleriyle pek çok alanda önemli gelişim ve dönüşümlere yol açarken, özellikle ekonomi ve siyaset bilimleri üzerindeki yaptırımları daha dikkat çekici olmaktadır. Ekonomi ve siyaset bilimlerinin birbirlerini etkileyen özel yapıları da bu çekiciliğin şiddetini artırmaktadir.

Oysaki klasik iktisadın doğduğu 18. yy’ın son çeyreği ve neoklasik iktisat anlayışının başat rol oynadığı 19. yy ortalarından itibaren, küreselleşme sürecinin en etkili olduğu alan ekonomi olmuştur. Ama 20. yy'ın ortalarına tekabül eden 2. Dünya Savaşı ve 1970'li yıllara damgasını vuran petrol şokları, küreselleşme olgusunun artık sadece ekonomik bir değer olmadığını, siyaset biliminin de yapı taşı olduğunu ve olmaya da devam edeceğini göstermiştir. 
Ekonomik küreselleşme çerçevesinde özellikle gelişmekte olan ülkeler aleyhine ortaya çıkan birçok olumsuz gelişmenin yaşanması (başta art arda gelen küresel krizler) ve bu olumsuzlukların etkilediği ülkelerde ortaya çıkan siyasi istikrarsızlıklar küreselleşmenin sadece ekonomik bir olgu olmadığını, aynı zamanda siyasi bir değer olduğunu oldukça acı bir şekilde ortaya koymuştur. Pek çok yazında küreselleşme kavramı "kapitalizm” ve daha da ileri giderek "emperyalizm” söylemleriyle birlikte anılır hale gelmiştir. Çünkü ulus devletin oluşumunu teşvik eden kapitalist yapı, günümüzde yeni ve farklı yapılanmalarla, ulus devletin meşruiyetini yok etmese de dönüştürmek amacıyla kendini yeniden yapılandırmaktadır. Bu anlayışı benimseyen gruba göre "sömürgeciliğin modern yüzü" olarak ifade edilebilecek emperyalizm olgusu, Fransız İhtilali sonrası yaygınlaşmaya başlayan “ulus devlet" oluşumlarının bir tür sonu olarak değerlendirilmeye başlamıştır.

'Ulus devlet' kavramı ilk anda akla getirdiği 'egemenlik' düşüncesi ile siyaset biliminin bir unsuru olarak algılanmasına rağmen; bir ulus devlet için egemenliğin ekonomik açıdan da ortaya konması gereği bu kavramın ekonomi biliminin de bir unsuru olarak değerlendirilmesi gereğini ortaya koymaktadır. Ulus devlet kavramına ekonomik açıdan yaklaştığımızda; devletin ekonomi politikalarını belirleme ve uygulama yetkisini egemenlik gücüne dayanarak elinde bulundurması ulusal anlamda ekonomik egemenlik, devletin diğer devletlere karşı bağımsız ulusal ekonomi politikaları saptaması ve uygulama yetisi ise uluslararası anlamda ekonomik egemenlik olarak tanımlanabilir.

$\mathrm{Bu}$ çalışma bağlamında ulus devlet anlayışının küreselleşme süreci içerisinde geçirdiği dönüşüm ve geldiği nokta özellikle ekonomik açıdan değerlendirilmektedir. Bu amaçladır ki çalışmanın birinci bölümü ulus devlet ve ekonomik egemenlik kavramlarını bağlantı ve çelişkiler açısından genel olarak değerlendirmektedir. İkinci bölüm ekonomik anlamda ulus devlet yapısının ulus üstü devlet yapılanmasına dönüşümünü uluslararası kurum ve kuruluşların rolleri çerçevesinde ele almaktadır. Üçüncü bölüm küreselleşme sürecinde demokrasinin inşası adına gerçekleştirilen müdahaleler ve ulus devlete etkilerini ortaya koymaktadır. Son bölümde ise küreselleşme sürecinin ulus devletler üzerindeki ekonomik egemenlik etkisi değerlendirilmektedir.

\section{ULUS DEVLET VE EGEMENLIKK UNSURU}

'Ulus Devlet' olgusunun ilk sorgulandığı anda ortaya koyduğu anlam milli değerler ve siyasi politikaların şekillendirdiği bir siyasi-politik düzendir ve Özyakışır (2006: 78) ulus devleti tanımlarken bu özelliği en yalın şekliyle vurgular. Leca (1998: 13-14) ise bu 
değerlendirmeyi genişleterek, ulus devleti, ulusal bir hükümetin elindeki gücü o ulusun yurttaşlarının eşitliği adına kullanmayı amaç edinmiş ve bu perspektifte çalışmalarını düzenleyen bir siyasi sistem olarak tanımlar.

Ulus devlet konusunda pek çok tanımlama yapmak mümkündür. Fakat tüm tanımlamalar bir şekilde birbirine benzer ifadeler olarak karşımıza çıkmaktadır. $\mathrm{Bu}$ çalışmanın amacı ulus devlet kavramını siyasi açıdan değerlendirmek olmadığı için, ulus devletin modern devlet olduğu şeklinde oldukça basit ama bir o kadar da anlamlı bir çıkarsamada bulunmak (Eşki Uğuz \& Saygıl1, 2016: 129), ulus devlet anlayışının küresel modern dünyadaki önemini anlatmak ve anlamak için vurgulayıcı olabilir.

Ünlü Otuz Yıl Savaşları'nın ardından 1648'de imzalanan Westphalia Barış Antlaşması; modern devlet anlayışını Avrupa'nın ve uluslararası düzenin siyasi birimi haline getirmiş, Fransız Devrimi (1789) ise modern anlamda ulus devletin ortaya çıkışına imkan tanımıştır (Tuncel, 2014: 41). Amin (2007: 180) bu durumu, Fransız Devriminin devletin mutlakıyetçi yapı içerisinde idari, adli ve iktisadi yapıyı merkezileştirerek, devlet ulusal yapısının bir dönüşüm sürecine girmesinin bir sonucu olarak değerlendirir.

Pierson (2000: 24), Weberian devlet anlayışına göre ulus devlet mekanizmalarını; (1) ülke, (2) meşru iktidar, (3) egemenlik, (4) meşruiyet, (5) şiddet araçlarının denetimi, (6) anayasallık, (7) kamu bürokrasisi ve (8) yurttaşlık şeklinde tanımladığı sekiz kategoride değerlendirmektedir. Yurdusev (2012: 64) ise ulus devleti (1) ülkesellik, (2) egemenlik, (3) merkezilik, (4) ulusallık ve (5) siyasi yapı şeklinde beşli bir sınıflandırmayla açıklamaya çalışmaktadır. Her iki değerlendirme şeklinde de açıklamalar birbiriyle örtüşen niteliktedir. Çalışmamızın kapsamı çerçevesinde bizim bakış açımız bu kriterlerden 'egemenlik' üzerinde yoğunlaşmaktadır. Egemenlik olgusu da 'ekonomik egemenlik' çerçevesinde ele alınmaktadır.

Davutoğlu (2003: 49) ulus devletlerde egemenlik olgusunun üç boyutta değerlendirilmesi gerektiğini ifade eder. $\mathrm{Bu}$ üç egemenlik unsuru ise şu şekilde açıklanmaktadır (Davutoğlu, 2003: 49-50): İç Egemenlik: Bir devletin kamu örgütlenmesini tamamlayarak kontrol mekanizmalarına sahip olduktan sonra kendisinden başka egemen kabul etmediği egemenliktir. Uluslararası Egemenlik: Egemen gücün başka devletler ile olan ilişskisini denetleyebildiği ve devletlerin birbirini tanıyarak oluşturduğu egemenliktir. Westfalyan Egemenlik: Dış güçlerin egemen gücü etkileyemediği egemenliktir. 
Bir ulus devlet modelinde devletin otoritesi ülkede bulunan herkesi kapsamakta ve devlet gücü dışında kalan herhangi bir otoriteyi hakim güç olarak kabul etmemektedir. $\mathrm{Bu}$ egemenlik türü genel olarak iç egemenlik olarak değerlendirilebilir. Ayrıca bir ulus devlet milli sınırlarından geçen her türlü bilgi, mal, kapital ve insan kaynakları üzerinde tam denetim yetkisine de sahiptir (Tekeli \& İlkin, 2000: 118). Bu egemenlik türü ise uluslararas1 egemenliktir. Çalışma kapsamında ele alınacak ekonomik egemenlik ise Westfalyan egemenlik içerisinde değerlendirilebilecek bir yapı gösterir. $\mathrm{Bu}$ egemenlik anlayışı dış güçlerin ulus devletin otoriter egemen gücü karşısında etkisizliğini ifade eder ki, aslında bu egemenlik anlayışında küreselleşmeyle birlikte bazı aşınmaların gündeme geldiği aşikardır. Fakat şu da gözden kaçırılmamalıdır ki ulus devletlerin ortaya çıkışı, ekonominin önem ve öncelik kazandığı kapitalist yaklaşımın benimsendiği 18. yy sonları ve 19. yy ilk yarısına denk gelmektedir. Coğrafi keşiflerle eş zamanlı olarak yükselen uluslararası ticaret sayesinde, merkantilizmde ön plana çıkan sermaye zenginliği ve fizyokratlarla gündeme gelen toprak ve tarımsal üretim aynı kalıpta eritilirken, kapitalizm sayesinde ortaya çıkan emek zenginliğinin de bu karışıma eklenmesiyle 'para-güç' ikilisi literatüre hiç sarsılmayacak şekilde yerleştirilmiştir. Nihayetinde kapitalizm üretim faktörleri olan emek, sermaye ve toprak çerçevesinde küresel bir kültür oluşmasını sağlayarak; bireysel girişimin doğmasına katkıda bulunmuş ve hükümetleri toplumsal sözleşmeler mantığı ile bu üretim faktörlerinin statülerini ayrı ayrı belirlemeye zorlamıştır (Sarıbay, 1992: 91-92).

\section{KÜRESELLEŞME İLE ULUS DEVLETTEN ULUS ÜSTÜ DEVLET YAPILANMASINA}

Küreselleşme olgusunu kapitalizm ve ulus devletin tarihiyle birlikte anmak mümkündür (Larsson, 2001: 9). Küreselleşme olgusuyla şekillenen dünya ekonomik düzeni uluslararası ticarette hakim güç olan serbest piyasa ekonomisi ve liberal anlayış, korumacılık ağırlıklı politikaların önemini yitirmesine sebep olmuştur. Günümüz dünyasında merkez ülkeler olarak kabul edilen gelişmiş batı ülkelerinin ulusal ekonomik ve politik tercihlerini oluşturup uygulayabilme güçleri bile, küresel piyasa aktörlerinin ekonomik ve siyasi ağırlığı karşısında etkinliğini kaybedebilmektedir (Hirst \& Thompson, 2003: 209). Bir diğer ifadeyle uluslararası piyasalar ulus devletlerden daha güçlüdür. $\mathrm{Bu}$ oluşumda küresel piyasa aktörlerinin ulus devletlerden daha rasyonel çalışıyor olmalarının ve ulus devletler her ne kadar ulusal bazda oldukça etkin olsalar da küresel bazda aynı etkinliği sağlayamamaları önemli rol oynar. 
Kazgan (2009: 18-19) serbest piyasa koşullarının genel kabulünün, ulus devletin ekonomik yetkilerinin önemli bir bölümünün uluslararası ve bölgesel kuruluşlara devredilmesini sağlayarak çok uluslu şirketler ile hükümet dışı örgütlerin ulus devlet üzerindeki belirleyiciliğini artırdığını, ayrıca yerel yönetimleri mali, idari ve ekonomik açıdan giderek özerkleştirdiğini ifade eder. Kazgan'ın bu ifadesini Somel'in yapmış olduğu şu açıklama da teyit eder niteliktedir: “AB, NATO, IMF, Dünya Bankası ve Dünya Ticaret Örgütü gibi uluslararası kurum ve kuruluşlar egemen sınıfların yürütme komitesi gibi çalışmakta ve bu kuruluşlar dayatmakta oldukları kültürü, politikayı ve değerler sistemini benimseyip uygulamayan ülkeleri terörist olarak kabul etmektedirler (Somel, 2004: 206207)". Kozanoğlu da (2004: 169) bu çerçevede uluslararası sermayenin, üretimi dünya ölçeğinde planlayarak her koşulda belirleyici rol aldığını ve koyduğu kurallara uymayanları cezalandırma politikası takip ederken de 'egemenliğini' her türlü zor ve baskı araçlarıyla dayattığını belirtmektedir. İnsanların kendi kaderlerini milli politik mekanizmalar ve kurumlar çerçevesinde belirledikleri bir devlet modeli olan ulus devletin sınırları, ya ulusal firmaların ya da ülke topraklarına yatırım yapmış uluslararası şirketlerin küresel boyutta rekabetçilik kabiliyetleriyle doğru orantılı bir konuma kavuşmuştur. Bu durum ulus devletleri rekabetçi olabilmek adına serbestlik ve özgürlüklerinden tavizler vermek zorunda bırakmıştır (Vaknin, 2002).

Türe $(2009$, 41) küreselleşmenin geleceğinin ulus devletin dayanma gücüne, ulus devletin geleceğinin ise küreselleşmenin baskısına bağlı olduğunu belirtir. Küreselleşmenin yarattığı yeni dinamikler, kurumlar, uluslararası örgütler ve sözleşmeler, hatta insan hakları konusunda oluşturulan normlar ve kurallar teorik açıdan bireyi devletle ilişkisindeki konumunda daha özgür ve daha güçlü olduğu bir yere yükseltmiştir (Dağı, 2005). Bu bağlamda yaşanan gelişmeler ulus devlet ulus üstü bir anlayışa geçişin ivmeleyicisi olmuştur. $\mathrm{Bu}$ geçiş sürecinde az gelişmiş ve gelişmekte olan ülkelerin başarılı olmaları, gerek sermaye, gerek tecrübe yetersizlikleri nedeniyle ulus devlet yapısının zayıflamasında önemli bir rol oynamıştır.

Cebeci (2008: 23) neoklasik düşünce ve onun getirisi olan küreselleşmenin dünyada hızla yayılmasıyla bu yeni oluşumun kendi kurum ve değerlerini yarattığını ve yaşanan gelişmelerin sonucunda da küreselleşmenin kendi devletini kurarak, ulus devletlerin bu yeni dünya devletinden izole bir politika uygulamalarını imkansızlaştırdığını ifade eder. İşte tam bu noktada ulus devlet yapılanmasını tehdit eden önemli aktörler devreye girer ki bunlar; çok uluslu şirketler, uluslararası ve ulus üstü kuruluşlar ve uluslararası entegrasyonlardır. 
Buksur'un (2013: 243) küreselleşme sürecinde ulus devletlerin sahip olduğu farkl1 etnik kimlikler açısından uluslararası mekanizmaların çalışma şeklini incelediği çalışma sonuçları da, küreselleşme ile birlikte ulus devletin temel niteliklerinin birçok açıdan aşındırıldığı ve ulus devleti yeniden şekillendirdiğini ortaya koymaktadır.

Behr'nin (2008: 360) 'küreselleşmenin paradoksu' şeklinde ifade ettiği durum, küreselleşme sürecinde devletlerin ulusallığının çözülmesi ve devletin dönüşmesi meseleleri arasındaki çelişkiyi anlatır. Küreselleşmeyle birlikte ülkeler arasındaki ilişkilerin artması ulus devlet anlayışıyla ulusal sınırlar arasındaki bağın zayıflamasına ve bu zayıflama ulus üstü aktörlerin ulus devletlerin ekonomik ve siyasi yapılarına müdahalelerine ve sonuç olarak da ulus devletlere yönelik ulus üstü tehditlere kadar varan bir yapılanmaya fırsat verir.

Habermas'a göre (2000: 204), günümüzde devletlerin sınırları içerisinde faaliyet gösteren ulusal ekonomilerin yerini, ekonomik piyasalar içerisinde faaliyet gösteren devletler almıştır. Ulus devlet anlayışının aşınması olarak ifade edilebilecek bu süreç ulus devletlerin ekonomik yönetim mekanizması ve devletin meşruiyeti için gerekli niteliklerini kaybetmesine neden olmaktadır (Habermas, 2000: 206).

Ulus devletler küresel ekonomik düzenin bir getirisi olarak, hem uluslararas1 ekonomik birleşmeler, hem de uluslararası ekonomik kuruluşlarla sıkı bir birliktelik içerisinde bulunmaktadırlar. Bu birliktelik bazen zorunlu, bazen gönüllü bir ilişki ortaya koymakta, fakat sebep ne olursa olsun ulusal ekonomileri birbirine sık1 bir şekilde bağlamaktadır. Bağl1lı̆̆ın derecesi ve ülkeler üzerindeki etkileri ise birlikteliğin özelliğine ve bu birlikteliği onaylayan ülkenin gelişmişlik düzeyine göre olumlu, olumsuz ya da nötr sonuçlar doğurabilmektedir. Nihayetinde bu sonuçların ekonomik içeriğinin yanı sıra, siyasi ve askeri içerikleri de ulus devletler üzerinde baskılar doğurmaktadır. $\mathrm{Bu}$ sürecin kaçınılmazlığı da mevcut sistem çerçevesinde oldukça aşikardır.

Küreselleşmenin temel yapı taşını oluşturan ve etkinliğini yoğunlaştıran bilgi işlem teknolojilerindeki gelişmeler olduğuna göre; küreselleşme süreci genel olarak gelişmiş kapitalist ülkelerin hayat verdiği çok uluslu şirketlerin ve ulus üstü toplumsal kurum ve kuruluşların eseridir. Bu bağlamda, ulus devlet kavramının özünde, gelişmiş dünyaya ait değerleri ve kültürleri barındırdığı açık bir şekilde görülebilir. Ayrıca küreselleşme bir ulus devlet için ister bir tehdit ister bir firsat olarak değerlendirilsin sonuç asla değişmeyecektir: Küreselleşme ulus ve devlet kavramlarının içeriğini her halükarda değiştirmekte ve ulus devlet anlayışını da değişime ve dönüşüme sevk etmektedir. Bu konuda Ateş (2006: 34-35) 
ulus üstü kurum ve kuruluşların ulus devletlere yönelik yaptırım baskıları nedeniyle, ulus devletlerin günümüzde, farklı ulusal kesimlerin taleplerinin eşit şekilde değerlendirilmesi hususunda adil davranmadığını ifade etmektedir.

Küreselleşmenin artan ivmesiyle birlikte özellikle mal ve sermayenin serbest dolaşımı ulus devlet hükümetlerinin ekonomi politikaları üzerindeki kontrollerinin zayıflamasına neden olmuştur. Ayrıca bu zayıflama küresel düzen içerisindeki ulus devletlerin döviz kurlarının da sistematik olarak birbirine bağlanmasıyla para politikalarının ulusal düzeyde belirlenmesinin önünde bir engel ortaya koymuştur (Bakan \& Tuncel, 2002: 58). Çokuluslu şirketler ise; teknoloji üretimi ve küresel ekonomiye hizmet sunma noktasında refah ve istihdam yaratarak toplumun yaşam standardını artıran, ulus devletlerin eksik kaldığı istihdam politikalarını ele alan ekonomik birimler olarak kendisini göstermişlerdir (Aktan \& Vural, 2008: 6).

Ulus devletlerin özerk ekonomi politikaları, uluslararası kurum ve kuruluşlara üyelik sürecinde imzalanan anlaşmaların getirdiği yaptırımlardan da etkilenmektedir. Özellikle küresel ticaret ve sermaye hareketlerinin düzenlenmesi için imza altına alınan bazı anlaşmalar bu süreci tetiklemekte ve ulus devletlerin ulusal ekonomi politikalarını belirlemelerinde etkin rol oynamaktadır. Örneğin; Çok Taraflı Yatırım Anlaşması (MAI) ulus devletlerin yabancı sermaye ve yatırımlar üzerindeki her türlü engel ve kısıtlamayı kaldırmasını; Mali Faaliyet Hedef Grubu (FATF) kara paranın aklanmasına yönelik tedbirler konmasını; Kamu Yönetiminde Etik Anlaşması (EPM) ise davranış kurallarına uyma mecburiyetini getirmektedir (Alagöz, 2005: 6-7). Bahsi geçen bu ve benzeri anlaşmalarla ulus devletlere tavsiye edilen politik uygulamalar neticesinde ulus devlet hem özerk politika belirleme yetisinde aşınmalara, hem de ekonomik tavizler nedeniyle mali ekonomik kayılara maruz kalmaktadır.

\section{III.I. Uluslararası Ekonomik Birleşmeler / Bütünleşmeler ve Ulus Devlet}

Ekonomik düzende meydana gelen değişim ve dönüşümler, merkez ülkelerin ulusal çıkarları doğrultusunda dünya ekonomilerini yönlendirmeleri ile şekillenmektedir. Bu amaçla inşa edilen ve sıklıkla uygulama alanı bularak yaygınlaşan oluşumlar ise uluslararası ekonomik entegrasyonlar olarak kendisini göstermiş ve özellikle bölgesel çaplı organizasyonlar şeklinde hayata geçmiştir. Bu bölgesel yapılanmalar öncelikle rakip ülkelerle ekonomik çerçevede bir birliktelik amacını güderken, zaman içerisinde siyasi bir birlikteliğin de mevcut amaca oldukça güçlü bir şekilde eklemlendiği gözlenmektedir. (Dünya ekonomik 
bütünleşmesinde en başarılı örnek Avrupa Birliği (AB)'dir. AB Kurucu Antlaşmaları'nda önceliğin ticari liberalizasyon konusuna verildiği ve ileri aşamalarda bir siyasi ve parasal birlikteliğe doğru evrildiği görülür. Ayrıca ekonomik birlikteliklerde ilk oluşumların bölgeselleşme hareketleri olarak kendini gösterdiği söylenebilir. (En başarılı örnekler olarak $A B$ ve NAFTA'da olduğu gibi.) Bu ekonomik bölgeselleşme hareketlerinin coğrafi yakınlığa sahip ülkeler arasında ticari faaliyetleri artırmanın ve küresel ekonomiyi üye ülkeler lehine yönlendirmenin en uygun formülü olduğu düşünülmektedir. Sonuç itibariyle ekonomik küreselleşme sürecindeki başarı, bölgeselleşme sürecindeki başarıya bağlı olarak tesis edilebilecektir.

Bölgesel bir arenada başlayan ekonomik entegrasyon hareketlerinin zaman içerisinde kimlik değiştirerek hem daha küresel hem de daha siyasi bir yapıya dönüşmeleri ile ulus devlet ve klasik egemenlik anlayışının da değişmeye başladığı söylenebilir. Ulusal egemenlikte bir aşınma olarak değerlendirebileceğimiz bu oluşumda en önemli etken olarak; uluslararası kuruluşlara üyelik ve uluslararası antlaşmaların kabul edilmesi, devletlerin kendi istekleri ile egemenliklerini sınırlandırmaları ve egemenliğin "tek" ve "mutlak" olan yapısını değiştirmeleri gösterilebilir. Zira, sistemde tek başlarına kendilerini devam ettirme ihtimallerinin çok zor olması, devletleri bu şekilde davranmak zorunda bırakmaktadır.

Ulus devletlerin uluslararası ekonomik entegrasyonlara üyelikleri ve dış ilişkilerini imzaladıkları uluslararası anlaşmalarla yönlendirmeleri neticesinde, söz konusu birliklerin kuralları uluslararası hukuk kuralı olarak kabul edilmektedir. Bu üyelikler sonuç itibariyle uluslararası hukukun, ulus devlete ait ulusal hukukun üzerine çıkmasına imkan tanımakta ve ulus devletlerin dış egemenlik alanlarını sınırlandırmaktadır.

Ulus devlet yapısının ekonomik entegrasyonlara üye olmak neticesinde karşılaştığı sıkıntıyı bir başka açıdan da değerlendirmek mümkündür. Sermayenin küreselleşmesi kapitalizmin nihai aşaması olarak değerlendirilebilir. Sermayenin küreselleşmesinin hız kazanmasıyla, küreselleşmenin başlangıcından itibaren sınırlarını korumak isteyen ulus devletler, sermaye ve emek faktörlerinin sınır ötesi hareketliliğini sağlayabilme konusunda oldukça büyük zorluklarla karşılaşmışlar ve bu hareketliliği kolaylaştırabilmek adına farklı bağlantı elemanları oluşturma yoluna gitmişlerdir (Brenner, 2004:46). Bu bağlantı yollarından en önemlisi uluslararası ekonomik birleşmeler ve bütünleşmeler olarak kendisini göstermektedir. 
Günümüzde ulus devletlerin ekonomik egemenlik dereceleri öncelikle, bağlı oldukları ekonomik bütünleşmeler ve bu bütünleşmelerin niteliğine bağlı olarak oluşur. İdikut Özpençe ve Özpençe (2007: 10) bu durumu açıklarken, özellikle ekonomik bütünleşmeler içerisinde vergilendirme yetkisinin üye devletler arasında belli alanlarda karşılıklı olarak kullanılmasından "vazgeçilmesi” ya da bütünleşme ile oluşturulan kurumlara "devredilmesi” şeklinde geliştiğini belirtir. Ekonomik bütünleşmenin derecesi arttıkça -Serbest Ticaret Bölgelerinden Siyasi Birlik aşamasına yaklaştıkça- üye ülkelerin ulus devlet niteliği aşınmakta ve ekonomik egemenlik yetkisi ulus devletin üstündeki ulus üstü devlet yapılanmasının eline geçmektedir.

\section{III.II. Uluslararası Kuruluşlar ve Ulus Devlet}

Uluslararası kuruluşların ulus devletlerin ekonomi yönetimi ve dolayısıyla ekonomi politikaları üzerindeki yaptırım güçleri de artmaktadır. Uluslararası kuruluşların yaptırım güçlerindeki bu artışın sebebi ise küresel düzen içerisinde tüm ülke ekonomilerinin birbirleriyle olan ekonomik bağlantısı olmaktadır. Sonuç itibariyle bu kuruluşların ülke yönetimlerine olan ilgisi artmakta ve sağlanacak ekonomik yardımlardan yararlanabilmek, önerilen yapısal reformların kabulüne bağlı olmaktadır. IMF, Dünya Bankası, Dünya Ticaret Örgütü gibi geniş bir katılımcı potansiyeline sahip kuruluşlar özel sektörün ağırlıklı olarak söz sahibi olduğu bir ortamda çalışabilmesini sağlayarak, serbest piyasa ekonomisinin işlerliğinin artırılmasını hedeflemekte, bir anlamda kapitalist sistemin bir tür destekçisi olarak işlem görmektedirler.

Ulus devlet anlayışı, güçlü bir merkezi yapının varlığı temeline oturmakta ve devletin toplumsal adaleti sağlayabilmesi için ya tüm kaynaklara sahip, ya da yönlendirici güç olması gerekliliğine dayanmaktadır. Fakat serbest ekonomi, özelleştirme, yerel yönetimlere yetki devri gibi merkezi devletin görev ve fonksiyonlarını daraltan uygulamalar ulus devlet anlayışında iktidar erimesinin önemli bir göstergesidir (Hirst \& Thompson 2003: 203-209).

Uluslararası ekonomik kuruluşlar, küresel düzenin tesisi, uygulamaların sorunsuz bir şekilde devamlılı̆̆ ve uluslararası ekonomik krizlerin ortadan kaldırılması gibi nedenlerle ulus devletlerle sıkı bir ilişki içerisine girmektedir. Bu uluslararası kuruluşların serbest pazar ekonomisini yaygınlaştırmak adına, devletin ekonomi içerisindeki payını azaltan, para ve maliye politikalarını şekillendiren bir uygulama ortaya koyduğu ifade edilebilir. Ek olarak ulus devletlerin bu kuruluşlardan özellikle finansal destek alabilmek için çeşitli anlaşmalar imzalaması neticesinde, ulus devletlerin söz konusu bağlayıcı hükümler ile egemenlik 
alanları daralmakta ve devletlerin refah seviyelerinde azalmalar gözlenmektedir (Cohen, 2001: 85).

IMF ve Dünya Bankası finansal destek isteyen ülkelere, uluslararası alacaklıların çıkarlarına uygun bir şekilde makroekonomi politikalarını düzenlemeleri yönünde bask1 yapabilmektedir. $\mathrm{Bu}$ baskıların nedeni, özellikle az gelişmiş ve gelişmekte olan ülke ekonomilerinin finansal sıkıntılarının büyüklüğü ve bu sıkıntıların ulusal kaynaklarla giderilme şansının azlığıdır. Bir tür bağımlılık olarak ifade edebileceğimiz bu süreç; IMF ve Dünya Bankası başta olmak üzere uluslararası finans kuruluşlarının, ulus devletlerden ulusal kambiyo rejimlerini serbestleştirmelerini istemeleriyle sonuçlanmakta, nihayetinde bu ülkelerin bağımsız para, faiz ve döviz kuru politikaları izleme imkanları sınırlandırılarak bu ülkelerin özerk politikalarını belirleme ve uygulama imkanları büyük ölçüde ellerinden alınmaktadır (Yeldan, 2002: 19). Yaptırım olarak değerlendirebileceğimiz bu politikaların temel yapısında ise özelleştirmeler, deregülasyonlar ve serbest piyasa ekonomisini canlandıracak her türlü ekonomik yapılanma yer alır. Devlet bütçesindeki açığın kapatılması için de genel tavsiye, kamu harcamalarının kısılması ve vergiler başta olmak üzere kamu gelirlerinin artırılması şeklinde kendisini göstermektedir. Sonuç itibariyle tüm bu yönlendirici düzenek, ulus devletin ekonomik egemenliğini sınırlandırıcı yaptırımlar olarak düşünülebilir.

\section{III.III. Çok Uluslu Şirketler ve Ulus Devlet}

Uluslararası kurum ve kuruluşların yanında çok uluslu şirketler de ulus devletlerin ekonomik faaliyetlerini etkileyen önemli bir baskı unsuru oluşturur. 1980 sonrasında etkinlikleri hızla artan bu şirketler, ulus devletlerin ekonomik egemenliğini tehdit eden önemli boyutlara ulaşmış durumdadır. Bu şirketler, çoğu zaman ulus devletlerin ekonomik politikalarını yönlendirerek pek çok ulusal ekonomi politikasından taviz vermelerine ve işlev değiştirmelerine kadar varan yeni ekonomik süreçlere girmelerine neden olabilmektedir. $\mathrm{Bu}$ etkileşim özellikle 20. yüzyılda kendisini ağırlıklı olarak hissettiren yeni ekonomik düzen ile ağırlık kazanmış ve ulus devletlerin hukuksal ve ticari bariyerler neticesinde bu şirketlerin ticari ve ekonomik baskılarını engelleyememelerine sebep olarak, çok uluslu şirketlere uluslararası ekonomiyle birlikte ulusal ekonomiyi de kontrol etme gücünü vermiştir.

Somel (2004: 201) çok uluslu şirketlerin ulus devletler karşısında tarafsız olduğunun iddia edilmesine rağmen, bu şirketlerin bir sahibi ve sahiplerinin de bir milliyeti olduğu görüşünden yola çıkmakta ve bu şirketlerin merkez ülkelerin bir uzantısı olarak görülmesi gerektiğini ifade etmektedir. 
Baram (2009) çok uluslu şirketlerin az gelişmiş ve gelişmekte olan çevre ülkeler tarafından çok büyük bir memnuniyetle karşılanan yatırımlarının, çoğunlukla sömürücü, tehlikeli ve vicdansız bir yapı sergilediğine dikkat çeker. Gerçekten de çevreye ve insan sağlığına zarar veren pek çok üretim sahasının çok uluslu şirketler aracılığıyla adı geçen ülkelere kaydırıldığı gözlenmektedir. Yatırımın yapıldığı ulus devletler ise, ne çevre kirliliği, ne işçi sağlığı, ne de doğal kaynak sömürüsü konularında herhangi bir düzenleme yapmadan bu yatırımlara kapılarını açmakta ya da açmak zorunda kalmaktadır.

Bununla birlikte ilerleyen süreçte, uluslararası ticari ilişkileri düzenleyen hukuki mevzuatların da çok uluslu şirketlerin konumlarını daha da güçlendirmek üzerine değiştirilmesi, bu şirketleri daha da güçlü bir yapıya kavuşturmuştur. Tüm bu yaşanan gelişmeler karşısında 'ulusal çıkar' kavramı hızla anlamını yitirmeye başlarken, serbest pazar anlayışının ana teması olan 'kar maksimizasyonu' kavramının birincil hedef olarak kabul edildiği yaklaşım ortaya çıkmıştır. Bu gelişmelerin en iyi örneğini ise ABD önderliğinde ticaretin genel esaslarını belirlemek amacıyla hazırlanmış olan Yatırımlar Hakkında Çok Taraflı Anlaşma (MAI) temsil etmektedir. MAI, çok uluslu şirketleri, ulusal devletler karşısında önceleyen ve devletlerin egemenlik alanlarını daraltan bir nitelik göstermekte olup, MAI'nin getirdiği hak ve imtiyazlardan çok uluslu şirketlerin yararlanmasına imkan verirken, sorumlulukları hükümetlere ihale eden bir yapı sergiler (Kiraz, 2012: 99-100).

Çok uluslu şirketlere sağlanan ekonomik ve ticari imtiyazlar sayesinde uluslararası şirketler, giderek belirli bir ulus devlette sadece ticari faaliyet gösteren çokuluslu şirketlerden, hiç bir ulus devlete bağlılık duymayan ulus üstü şirketlere dönüşmektedirler. $\mathrm{Bu}$ sürecin sonunda da uluslararası sermayenin çıkarları ile ulus devletlerin politikaları çatışmaya başlamakta ve bu çatışmanın yanı sıra, ulus devletler, kendi ülkelerinde faaliyet gösteren bir grup uluslararası ekonomik gücün çıkarlarını savunan ve politik işlevselliği yanında ekonomik işlevselliği de gün ve gün azalan ekonomik kurumlar konumuna düşmektedir. Hatta Kongar (2001: 36) ulus devletler ile çok uluslu şirketler arasında hukuksal sorunlar baş gösterdiğinde bunu çözecek merci olarak, ulus devletin yargı organlarının değil; uluslararası bağımsız tahkim kurullarının devreye girdiğini ve bu surette ulus devletlerin kendi toprakları üzerindeki yargı gücünü kullanma yetkilerinin uluslararası hukuk aracılığıyla kısıtlandığını ifade eder.

70’li yıllara damgasını vuran 'Petrol Krizi' ile şekillenen 'yeni ekonomik düzen', uluslararası boyutlu ekonomik programların hazırlanarak ulus devletlerce uygulanması dayatılmış bir dizi ekonomik programı içerisine almaktadır. Bu program çerçevesinde 
devletin asli görevleri dışında, ki bu özellikle ekonomik alandır, yer alan tüm faaliyet alanlarından elini çekerek devleti minimalize edecek ve serbest pazar ekonomisinin etkinliğini artıracak bir yapılanmadan bahsedilmektedir. Bu amaca hizmet eden uygulamalar neticesinde pek çok ulus devlet ekonomisi ağır darbeler almış, asıl önemlisi bir takım uluslararası sermaye grupları (başta çok uluslu şirketler olmak üzere) ulus devletin ekonomik egemenlik sınırları içerisinde bir fiil faaliyet göstermeye başlamıştır. Tüm bu yaşananlar Eken'in ifadesiyle (2006: 256-258), ulus devlet ekonomilerinin küresel düzene entegre olmasını sağlarken, aynı zamanda ulus devletlerin dış borca saplanmasına, ithal sanayici bir anlayışın egemen hale gelmesine, gelir adaletsizliğinin artmasına, sermaye piyasalarının olumsuz etkilenmesine; kısaca ulus devletin işlevsiz kılınarak ekonomik egemenliğin uluslararası kuruluşlar ve çok uluslu şirketler ile paylaşılmasına firsat tanıyabilecektir.

Gerçekten de çok uluslu şirketler ulus üstü yapıları sayesinde finansal sermayenin hareketliliğini oldukça kolay bir şekilde sağlayabildikleri gibi; yatırım alanlarının belirlenmesi çerçevesinde ulusal ekonomi politikalarını etkileme yeteneğine sahip bulunmaktadırlar. Fakat çok uluslu şirketlerin elindeki bu güç çoğu zaman ulus devletler ile uluslararası sermayedarların çıkarlarının çatışmasına neden olmaktadır. Fakat bu çatışmalar ulus devlet ekonomilerinin çok uluslu şirketlere olan ekonomik bağımlılığı nedeniyle genellikle çok uluslu şirketlerin talepleri doğrultusunda çözüme kavuşmaktadır. Süreç her ne kadar bu şirketlerin lehine çalışıyormuş gibi algılansa da, ulus devletlerin de bu ortaklıktan olumlu katkılar sağladığı bir gerçektir. Tek problem ulus devletin ekonomik egemenliğinde ortaya çıkan aşınmadır. Bu aşınmanın etkileri de bir başka araştırmanın ana konusu olarak değerlendirilebilir.

\section{DEMOKRASINIIN İNŞASI VE ULUS DEVLET}

Küreselleşen dünyada uluslararası terörizm, organize suç örgütleri, siber terör, saldırma amacı güden devletler, konvansiyonel ve kitle imha silahlarının yaygınlaşmasının yanı sıra, finans piyasalarına saldırılar, refaha, çevreye, sağlığa yönelen tecavüzler ile göçler ve mülteci hareketleri gibi ulusal ve uluslararası çıkarları zedeleyen tehditler güvenlik ihlalleri olarak öne çıkmıştır (Erdoğan, 2013: 265). Hatta bu güvenlik ihlallerinin Soğuk Savaş sonrasında arttığı ve belirli ölçüde değişime uğradığı da gözlenmektedir. Soğuk Savaş öncesinde bu ihlaller çoğunlukla gelişmiş ülkeler tarafından gerçekleştirilirken, Soğuk Savaş sonrasında ise günümüzün az gelişmiş ülkelerini hedef almaya başlamıştır. Yine Soğuk Savaş öncesi güvenlik ihlalleri ulusal problem olarak görülürken, günümüzde uluslararası bir açık 
olarak değerlendirilmekte ve çözümünde uluslararası kurum ve kuruluşlardan yararlanılmaktadır.

Günümüzde bu tehditlerin oluşmasında ekonomik küreselleşme faaliyetlerinin hammadde zengini olduğu halde gelişmemiş/gelişememiş ülkelerdeki daha 1lımlı bir yapıya dönüştürülememesinin rolü büyüktür. Dönüşüm gerçekleşmedikçe de küresel ekonomi genişleyememekte, bir açıdan da kapitalizm tam anlamıyla egemenliğini ilan edememektedir. Açıça ifade etmek gerekirse hammadde zengini çevre ülkelerle, kapitalist merkez ülkeler arasındaki ekonomik ve siyasi görüş ayrılıkları, kültürel ve dini farklılıkların da eklenmesiyle küresel tehditler boyutuna taşınmaktadır. İşte bu nedenledir ki Jameson (2000: 39) günümüzde ulus devlet modelinin işlevsel açıdan yetersizlikle eleştirilmesini, bu modelin temel unsurları olarak ifade edilen milli egemenlik ve milli kimlik yapılanmasındaki tahribatla ilişkilendirmektedir.

Ulus devlet modelinin dünya ekonomileri içerisindeki hakimiyeti, insan hakları kavramının II. Dünya Savaşı sonrasına kadar, her devletin kendi iç işi olarak algılanmasına sebep olarak, bu hakların benimsenmesi ve uygulanmasında uluslararası örgütlenmelerden destek alınmasını gerektirmemiştir. Fakat Batı dünyasına yönelik küresel güvenlik tehditlerindeki artış neticesinde (2001 yılında ABD’ye gerçekleştirilen terör saldırısı sonrası) bu ülkelerin, zayıf devletlerin güçlü devletlere dönüştürülmesinin dünyada güvenliği artıracağına yönelik eylem ve söylemleri ulus devlet anlayışının aşınmasında önemli bir rol oynamıştır. Hatta bu süreçte, başta küresel terör eylemleri olmak üzere pek çok güvenlik açığının ve küresel tehdidin sorumlusu olarak görülen gelişmemiş devletlerin (Robinson, 2007: 1) güçlendirilmesi gereği uluslararası kurum ve kuruluşların en önemli görevi olarak benimsenmiş/benimsetilmiştir.

$\mathrm{Bu}$ zayıf devletlerin liberalizmin küresel özelliğine tehdit oluşturmayacak şekilde yeniden inşa edilmesinin bir zorunluluk olarak benimsenmesi Kaygusuz'a göre (2014: 27) güçlü devletler oluşturulmasını amaçlamamakta, hatta neo-liberal dönüşüm modeli de bu toplumlardaki güvensizlik ikilemini daha da derinleştirmektedir. Duffield da (2007: 7) benzer bir çözümlemeyle güçsüz devletler üzerinde adı geçen amaç çerçevesinde kullanılan yöntemlerin güçsüz ülkelerin siyasi krizlerini daha da artıracağı açıklamasında bulunmaktadır. Habermas ise (2002: 27-29) küreselleşmenin bir yandan dünyayı 'radikal demokrasiye' taşırken, diğer yandan 'demokrasi krizi' ya da 'demokrasi açıkları' yaratan bir yapı oluşturduğunu belirtir. Bravo (2005: 133) ise sömürgecilik gibi şiddet üzerine kurulmuş olan ve ulus devlet organizasyonundan bağımsız bir şekilde hareket eden küreselleşmenin, 
özgürlük, insan hakları ve demokrasi gibi mükemmel oluşumları yaygınlaştıracağı iddiasının doğru olmadığını ifade ederek bu açıklamalara son noktayı koymaktadır.

Serbest ticaret ve küreselleşme ile birlikte artan ve çeşitlenen toplumsal tüketim talebi -ki bu gören göz ister anlayışının eseridir- az gelişmiş toplumların da gelişmiş toplumların hayat standardına ulaşma isteklerini artırmakta ve çoğu zaman yasal olmayan emek göçlerine sebep olmaktadır. Bu güvenlik ihlalinin yapı taşı ekonomik yetersizliktir. Genellikle kalifiye olmayan bu insanların daha yüksek bir hayat standardı uğruna gelişmiş ülkelere kaçak olarak girmesi ise peşi sıra pek çok sorunu gündeme getirmektedir. Choucri'nin (2005: 46) ifadesiyle bireylerin daha talepkar yapıya bürünmeleri toplumsal, ekonomik ve siyasi sorunların yanı sıra göç tehdidinin de en önemli tetikleyicisidir.

Artan uluslararası güvenlik krizleri sonucunda, gelişmiş ülkelerin küresel düzenin devamlılığı için tesis ettiği kurum ve kuruluşlarca aşılması yönündeki müdahalelerinin uluslararası toplumu getirdiği son nokta ise, ulus devletin makroekonomik politikaların uygulanmasında dışarıya olan bağımlılığındaki artış ve ulus devletlikten ulus üstü devletliğe geçiş olmaktadır. Aslında bu durum açık bir ekonomik egemenlik ihlalidir.

\section{SONUÇ}

Dünyanın egemen devletlerden oluştuğu temel felsefesine sahip egemen devlet anlayışı, Avrupa'yı yerle bir eden ve "Otuz Yı1 Savaşları" olarak anılan savaşlar sonucunda imzalanan Westphalia Barışı (1648) ile hayat bulmuş bir devlet yapılanmasıdır. Ulus devlet anlayışı ise I. Sanayi Devrimi ile gelişip, Fransız İhtilali ile zirveye ulaşmıştır. Bir diğer açıdan ulus devlet anlayışının ortaya çıkmasında, ticari kapitalizm olgusunun da önemli olduğu düşünülmektedir ki; bu düşüncenin yapı taşını da Avrupa'da sanayi devrimi ile birlikte oluşan burjuvazinin, ekonomik alanda genel kabul gören kapitalist anlayışı siyasi alanda da inşa etmeyi amaçlaması tetiklemiştir. Kapitalizmin sürdürülebilirliğinde önemli rolü olan küreselleşmenin $1945^{\prime}$ lerden itibaren ulus devletleri hızla içerisine çekmesi ile ulus devletlerin artık eskiden olduğu gibi ticari kapitalizm için uygun ortamlar hazırlamadığının anlaşılması, günümüzün ulus devlet anlayışının yeniden şekillenmesi/şekillendirilmesi gereğini ortaya çıkarmıştır. Bir diğer ifadeyle ulus devleti yaratan kapitalizm, yine kendi eliyle ulus devleti yeniden şekillendirme gereği duymuştur/duymaktadır. Hatta bu evrilmede kapitalizmin sürükleyicisi olan küreselleşmenin rolü üst düzeydedir. Fakat şu da bir gerçekliktir ki küresel aktörler henüz ulus devletin yerini tam olarak alabilecek meşru nitelikte bir uluslararası örgütlenmeyi kurumsallaştıramamışlardır. 
Küreselleşme ile ulus devletlerin ekonomik egemenliği, uluslararası sermayenin egemenliğine dönüşmüş ve bu dönüşüm devam etmektedir. Küreselleşmenin gelişmiş ekonomiler üzerinde yarattığı olumlu etkiler (yüksek büyüme hızları gibi), ekonomik serbestleşmenin 90'lardan itibaren tüm dünyaya hızla yayılmasıyla iniş trendine girmiş, bu süreçte finansal krizlerden nasibini almayan hemen hemen hiçbir ülke kalmamış (özellikle gelişmekte olan ülkeler) ve bu ülkelerde işsizlik, fakirlik artarken arkasına gelişmiş ülkelerin desteğini alan küçük bir azınlık finansal anlamda gittikçe büyümüştür. Bu küçük azınlıkların ise genellikle ulus devlet yapısı içerisinde varlık gösteren ve siyasi yönetime yakın olanlardan oluştuğu dikkat çekmektedir. Bu değerlendirme ise bize ulus devlet yapısının yok olmadığını sadece evrildiğini ve evrilmeye devam edeceğini anlatmaktadır.

Ticari kapitalizm için bir çıkış noktası olarak planlanan küreselleşme ile dünya ekonomisinde serbest piyasa/liberalizm anlayışının devamlılığı, ulus devletlerin bu yeni düzenin yeni oluşumlarından bağımsız politikalar oluşturma ve uygulama yeteneklerini büyük oranda baltalamıştır. Bu nedenledir ki günümüz ekonomik yapılanmasında herhangi bir ulus devletin, özellikle de az gelişmiş ve gelişmekte olan bir ulus devletin, mutlak ekonomik egemenliğe sahip olması adeta imkânsızdır. Bu imkansızlığın ortaya çıkmasında ise ulus devletlerle uluslararası kuruluşlar arasında imzalanan anlaşmaların uluslararası hukuku kurumsal bir yapıya kavuşturmuş olması önemli bir rol üstlenmektedir. Nihayetinde uluslararası anlaşmalar uluslararası kuruluşların ulus devletler aleyhine yetki alanlarını hızla genişletmekte ve uluslararası hukuk hızla irtifa kazanmaktadır.

Küreselleşmenin her piyasada aynı şekilde uygulanmadığı, örneğin gelişmiş ülkelerde sermayenin küreselleşmesi olabildiğince fazla teşvik edilirken, emeğin küreselleşmesine o kadar sıcak bakılmadığı da gözlenmektedir. Özellikle tarım ve tekstil ürünlerinin rekabetinde karşılaştırmalı üstünlüğe sahip olan gelişmekte olan ülkelere, gelişmiş merkez ülkelerce çeşitli yaptırımlar dayatılması da bir diğer çelişkidir. Yani küreselleşme bazı merkez ülkelerin elinde olan ve çevre ülkelere karşı kendi çıkarları doğrultusunda kullanılan bir maşadır. Bu maşanın ucunda da uluslararası anlaşmalarla güçlendirilmiş uluslararası ekonomik kurum ve kuruluşların yanı sıra çok uluslu şirketler yer almaktadır.

Hem uluslararası kurum ve kuruluşlar, hem de çok uluslu şirketler, dünyanın tüm ulus devletler için daha yaşanabilir bir yapıya kavuşmasını istediklerini her fırsatta ifade etmektedirler. $\mathrm{Bu}$ isteklerin gerçekleşebilmesinin ise ulus devletlerin (çevre ülkelerin) kendilerinden istenilen düzenlemeleri/yaptırımları yerine getirmelerine bağlı olduğunu vurgulamaktadırlar. Uluslararası kurum ve kuruluşlar finansal yardımlarını (dış borç), çok 
uluslu şirketler ise yatırımlarını bu tavsiyelere -tavizlere- uyulması koşuluyla gerçekleştirmekte ve sonuç itibariyle ulus devletler makroekonomi politikalarını belirlerken bu kurum ve kuruluşları memnun etmeye mecbur kalmaktadırlar.

Son bir söz söylemek gerekirse; küreselleşmenin getirmiş olduğu pek çok ekonomik olumsuzluk ve siyasi yozlaşmaya rağmen, bu yapının dışında kalmanın mümkün olmadığı genel kanaatine inanarak, güçlü ulus devletlere eskisinden daha çok ihtiyaç olduğu aşikardır. $\mathrm{Bu}$ bağlamda ulus devletlerden beklenen ise ulus devlet kimliklerinden taviz vermeden, ulusal çıkarlar çerçevesinde hareket edebilme güç ve yeterliliğine sahip olabilmeleridir. 


\section{REFERANSLAR}

Aktan, C. \& Vural, İ. Y. (2008). Globalleşme Sürecinde Çokuluslu Şirketler. http://www.canaktan.org/ekonomi/cok-uluslu/aktan-makale.pdf. (16.01.2017).

Alagöz, M. (2005). Küreselleşme ve Yeni Dünya Düzeninde Ulus Devlet Anlayışı. Akademik Baklş. Sayı:6, 1-9.

Amin, S. (2007). Avrupa Merkezcilik. M. Sert (Çev.). İstanbul: Çiviyazıları Yayınevi.

Ateş, D. (2006). Küreselleşme: Ne Kadar Tek Boyutlu?. Doğuş Üniversitesi Dergisi. 7(1), 25-38.

Bakan, S. \& Tuncel, G. (2012). Küreselleşmenin Ulus Devletler Üzerindeki Etkisi. Birey ve Toplum. Cilt.2, Say1.3, 51-65.

Baram, M. (2009). Globalization and Workplace Hazards in Developing Nations. www.sciencedirect.com_science. (12.01.2017).

Behr, H. (2008). Deterritorialisation and the Transformation of Statehood: The Paradox of Globalisation. Geopolitics. 13 (2). April, 359-382.

Bravo, I. B.(2005). Tarihin Sonu, İlerleme ve Küreselleşme Üzerine Bir İnceleme. Cumhuriyet Üniversitesi Sosyal Bilimler Dergisi. Cilt: 29, No:2, 125-138.

Brenner, N. (2004). New State Spaces, Urban Governance and Rescaling of Statehood. Oxford: Oxford University Press.

Buksur, A. (2013). Etniklik ve Uluslararası İlişkiler. Gazi Akademik Bakış. Cilt 6, Sayı 12, Yaz 2013, 243-263.

Cebeci, K. (2008). Küreselleşme Bağlamında Ulus-Devletin Egemenlik Gücünün Dönüşümü. Sayıştay Dergisi. 7(1) Ekim-Aralık, 23-39.

Choucri, N. (2005). Cross-border Movements of Populations in a Fair Globalization. Development. C. 48 , S. 1.

Cohen, E. (2001). Globalization and the Boundaries of the State: A Framework for Analyzing the Changing Practice of Sovereignty. Governance An International Journal of Policy and Administration. 141, 75-97.

Dağı, İ. D. (2005). İnsan Hakları, Küresel Siyaset ve Türkiye. Polis Dergisi. S. 45, 41-46.

Davutoğlu, A. (2003). Küreselleşme ve AB-Türkiye İlişkileri Çerçevesinde Ulusal Egemenliğin Geleceği. Anayasa Yargısı Dergisi. Cilt: 20, 46-58.

Duffield, M. (2007). Development, Security and Unending War: Governing the World of Peoples. Cambridge: Polity.

Eken, H. (2006). Küreselleşme ve Ulus Devlet. Selçuk Üniversitesi Sosyal Bilimler Enstitüsü Dergisi. Say1 16, 243-262.

Erdoğan, İ. (2013). Küreselleşme Olgusu Bağlamında Yeni Güvenlik Algısı, Gazi Akademik Bakış. Cilt 6, Sayı 12, Yaz 2013, 265-292.

Eşki Uğuz, H. \& Saygılı, R. (2016). Küresel Dünyada Ulus Devlet. Selçuk Üniversitesi İIBF Sosyal Ekonomik Araştırmalar Dergisi. Ekim, Y11:16, Sayı:32, 127-147.

Habermas, J. (2002). Küreselleşme ve Milli Devletlerin Akibeti. M. Beyaztaş (Çev.). İstanbul: Bakış Yayınları. 
Hirst, P. \& Thompson, G. (2003). Küreselleşme Sorgulanıyor. 3. baskı. Ankara: Dost Yayınevi.

İdikut Özpençe, A. ve Özpençe, Ö. (2007). Küreselleşme ve Uluslararası Kuruluşların UlusDevletin Vergilendirme Yetkisine Etkileri. Uluslararası Insan Bilimleri Dergisi. Cilt: 4, Sayı: 1, 1-21.

Jameson, F. (2000). Küreselleşme ve Politik Strateji. Birikim. 139 Kasım, 39-50.

Kaygusuz, Ö. (2014). Devlet İnşası ve Küresel Güneyde Güvenlik: Güçlü Devlet Arayışının Kuramsal ve Siyasal Açmazları. Uluslararası Hukuk ve Politika. Cilt: 10, Sayı 39, 27-61.

Kazgan, G. (2009). Küreselleşme ve Ulus-Devlet Yeni Ekonomik Düzen. İstanbul: Bilgi Üniversitesi Yayınları.

Kiraz, S. (2012). Uluslararası İlişkilerde Egemenliğin Değişen Yüzü. Niğde Üniversitesi İIBF Dergisi. 5 1, 93-102.

Kongar, E. (2001). Küresel Terör ve Türkiye, İstanbul: Remzi Kitabevi.

Kozanoğlu, H. (2004). Küreselleşme ve Uluslarüstü Sermaye Sınıfı. Doğu-Batı Dergisi. Yı1 5, Say1 18.

Larsson, T. (2001). The Race to the Top: The Real Story of Globalization. U.S.: Cato Institute.

Leca, J. (1998). Neden Söz Ediyoruz?. J. Leca (Ed.). Uluslar ve Milliyetçilikler. S. İdemen (Çev.). İstanbul: Metis Yayınları, 11-19.

Özyakışır, D. (2006). Ulus-Devlet ve Milli Egemenlik Bağlamında Teorik Bir Küreselleşme Eleştirisi. Jeopolitik Dergisi. Y11: 5, Say1: 31, 78-80.

Pierson, C. (2000). Modern Devlet. D. Hattatoğlu (Çev.). Ankara: Çivi Yazıları Yayınları.

Robinson, N. (2007). State-Building and International Politics: The Emergence of A 'New' Problem Agenda. N. Robinson \& Aidan Hehir, (Ed.). State-Building: Theory and Practice. Abingdon: Routledge.

Sarıbay, A. Y. (1992). Siyasal Sosyoloji. Ankara: Gündoğan Yayınları.

Somel, C. (2004). Az Gelismislik Perspektifinden Küreselleşme. Doğu-Batı Dergisi. Yıl 5, Say1 18.

Tekeli, İ. \& İlkin, S. (2000). Küreselleşme Ulus-Devlet Etkileşimi Bağlamında AB-Türkiye İlişkilerinin Yorumlanması. Doğu-Batı Dergisi. (10) Şubat-Mart-Nisan, 113-138.

Tuncel, G. (2014). Ulus Devletin Dönüşümünde Hükümet D1şı Örgütlerin Etkisi, Atatürk Üniversitesi İktisadi ve İdari Bilimler Dergisi. Cilt: 28, Say1: 2, 39-54.

Türe, İ. (2009). Küreselleşme, Kapitalizm ve Ulus-Devlet. Finans Politik \& Ekonomik Yorumlar Dergisi. (46) 530, 41-52.

Vaknin, S. (2002). Analysis: The Industrious Spies -III. United Press International. 15 May1s 2002.

Yeldan, E. (2002). Neo liberal Küreselleşme İdeolojisinin Kalkınma Söylemi Üzerine Değerlendirmeler. Praksis. Sayı:7, 19-34. 
Yurdusev, A. N. (2012). Ulus Devlet: İnsanlığın En Tehlikeli İcadı, T. Arı (Ed.). Uluslararası İlişkilerde Post Modern Analizler-1Kimlik, Kültür, Güvenlik ve Dış Politik. Bursa: MKM Yayinc1lik, 59-74. 